\title{
1. Myths, narratives and welfare states: an introduction
}

\subsection{INTRODUCTION}

The development of welfare states is often portrayed by looking into issues of spending, replacement rate and conditionality of social benefits. Change related to the legitimacy of and political preferences - from right to left and opinions - on the role of the state and the need for state intervention is also often examined. It is argued that welfare states have, with variations over time and between countries, been in crisis since at least the beginning of the 1980s (OECD 1981). Part hereof was a negative view on the ability of Keynesian demand management to solve economic problems, including high levels of unemployment, economic stagnation and inflation. At the same time, there has been the perception of a stronger influence from monetary and liberal economic ideas, again with variations across welfare states. In the wake of the financial crisis, austerity, retrenchment and the impact on welfare states' development have also been discussed extensively, including with reference to issues such as welfare chauvinism and populism, but also whether, in fact, there has been austerity in all welfare states (see for details Greve 2019, 2020a).

One could perhaps argue that the development in welfare states is not only influenced by development in economic options, but presumably also by the myths about who gets what in the different welfare states, or to put it in another way, the narratives of how welfare states work, function and fulfil the goals of welfare states. This is in line with recent research, for example, within economics (Shiller 2019). Narratives are often used in analysis with a more qualitative approach, where the narrative, for example, can represent the perspective of users and/or workers in welfare states. It can also represent those paying for welfare, and those not getting what they expected to get. Self-interest can also be part of the support or not for spending in welfare states or at least part hereof (Laenen 2018). Myth and narratives may have caused a change in welfare states' legitimacy. Analysis has therefore looked into people's perception of how the welfare state functions, the level of support to different policy areas (such as high levels for health, pensions and long-term care) often being framed as part of a classical discussion on deservingness. 
However, as deservingness cannot theoretically be defined, as is the case for another often used concept "need", this raises the question of how narratives of the way in which societies function might have an impact on welfare states' development. Labels such as welfare queens, scroungers and skivers indicate part of the debates on the possible impact on welfare states' development of narratives (Jurado and Brochmann 2013; Cromby and Willis 2014). This can also be reflected in the understanding of how different kinds of myths have an impact on how policy makers make decisions. Different myths and their possible impact on welfare states' development will be the continuous theme throughout the book. This can also be related to what is called the Thomas theorem "that if people define situations as real, then they are real in their consequences" (Svallfors 2012, 26).

Overall, the book thus presents a number of myths about welfare states, and further raises the question of whether different myths and narratives have or have had an impact on welfare states' development. This is not necessarily on overall development, but on change in their structure and composition. It will analyse a number of these myths after having first discussed the central concepts to be used in the book. The data used in the book include a number of surveys. For example, the European Social Survey (2018 data) $)^{1}$ includes a question on whether immigrants make a country better or worse, and the survey from round 8 in 2016 has data on welfare attitudes and fairness. The European Quality of Life Survey (2016) includes questions related to trust, perception of social exclusion, social cohesion and so on. The World Value Survey, the European Value Survey and Eurobarometer are also used to look into some of the issues related to the perceptions among citizens on a number of narratives. Data on perceptions of levels of benefits, for example, and how they relate to actual benefit will also be included as far as possible. The use of core words and how this has developed, using Google Ngrams and ProQuest News and Newspaper, will be seen as an indicator of how these might have influenced welfare states. Using international data and studies is an important way to ensure a comparative approach in depicting whether narratives might have a different influence across different types of welfare states. Dependent on data availability, there will mainly be a focus on European welfare states from different welfare regimes, although reference to a number of other cases, especially the US, is also included. A comparative approach can help in trying to understand whether there is a common trend or whether we are witnessing differences depending on the type of welfare regime we are within.

Thereby, the book will disentangle central myths and narratives about the welfare states, and how this can have, and might have had, an impact on welfare states' development, including referring back to debates on welfare chauvinism and deservingness (Van Oorschot 2006; Greve 2019). It will also discuss why some myths might be more persistent and why some stories 
seemingly have a stronger impact than others. The cherry picking of information among decision makers might also influence development, as well as - possibly directly - fake news. The myths might both imply higher as well as lower spending in welfare states as well as in the tax and duty system. This also includes attitudes towards the welfare state and the possible changes over the years, as these changes can be argued to be part of how myths and narratives can have an impact on welfare states' development. Some of the issues related to attitudes, including how a myth is related to "suspicions about welfare abuse and cheating" (Svallfors 2012, 6), might also include negative views on the administration of the welfare states, but this is not central to the analysis.

One example of the policy use of myths is the phrase used for change in several countries "there is no alternative" sometimes labelled the TINA argument (Jensen and Tyler 2015), which was used especially in the wake of the financial crisis, but also as part of the consequences of the pressure on welfare states due to the ageing of populations and globalization.

The impact of narratives and myths on welfare states' development is at the core of this book. Still, an important question is how they are able to have an impact. This will not be the central aspect of the book; however, one condition seems to be the availability of connectors. A good illustration of why this is important is that in 1775 two persons tried to warn people in Boston that the British were coming their way. They rode in different directions to warn people and to get a militia ready to take on the British; one succeeded, whereas the other one didn't. The successful person was what Gladwell called a connector (Gladwell 2006). The task was more difficult at that time as there was the need to get in contact directly with many persons, whereas today the net can be used in many and different ways to influence what will go viral; although, here also some influencers work better than others. Thus, having easy access to communication with others with the same opinion might also influence opinions, and might also be the reason why discussions about different perspectives are, perhaps, more difficult now than they used to be.

Another possible way in which myths influence is by blame-avoidance strategies, because by blaming someone it might be possible to avoid electoral punishment for the reduction in benefits as framing can affect attitudes towards changes (Wenzelburger and Hörisch 2016). Thus, policy makers might use myths as a way to get changes through and perhaps even to hide who are the winners and losers of the changes if they have found a scapegoat. Furthermore, policy feedback is a way in which myths have an impact, including how to find "the causal mechanisms linking public opinion with public policy" (Béland and Schlager 2019, 200). This is mainly done indirectly by linking knowledge on perception and attitudes with the actual development in welfare states.

A separate problem is that with modern media, people often look at forums where they are already in contact with someone they agree with, which then 
confirms their perception of what is right. One consequence may be that even if the myths are not true, they are of such a nature that they affect the development of the welfare state. This includes the possible influence from different kinds of fake news, as indicated earlier. It also entails the risk that the current best knowledge may not necessarily be included in decisions on the development of the welfare state, in other words, that evidence-based knowledge is not sufficiently part of the decision-making process (Greener and Greve 2013; Greve 2017a). However, it might also mean that a narrative is one that only a few find to be correct, and thereby such a case might not influence the development.

Another issue is that simpler narratives "win" over the more complicated ones and, further, the complicated arguments when considering the advantages and disadvantages of different types of decisions are lost in translation. For example, numbers can be difficult to see for many, and at the same time, there may be many people who often quote the saying "There are three kinds of lies: lies, damned lies, and statistics?", thereby possibly neglecting the actual facts of the situation. When stories can be understood as intuitive, for example, because there is a good story that we can all remember quickly and easily, then it may have a greater likelihood of having an impact in relation to the development of social policies. To a large extent, this is why it is central to understand who in the public's opinion deserves to receive social services and who does not. It will become a central part of the discussion of legitimacy in both the individual parts of the welfare state as well as the overall development of the welfare state.

Legitimacy may thus come under pressure from a possible narrative related to whether or not there is abuse/cheating of public benefits and services even if by a few persons compared to the many who actually need the benefits and services. This also includes a lack of knowledge on the lives of people actually living in poverty. (For more on the analysis and description related hereto in a number of welfare areas, see Greve 2020b, 2020c.) Of course, living in poverty can in itself affect the behaviour of the individual (McGarvey 2018). Therefore, there may also be individuals who receive social benefits to which they are not entitled, but where this is solely due to a lack of knowledge of the rules. Basically, this is no different to someone who does not pay the tax they owe because they misunderstand the tax rules. This can further be related to, and presented as, a them and us approach. The "us" is thereby often the hardworking person paying the correct taxes and duties, whereas "them" is a different group who are perceived to (mis)use the welfare system instead of working. However, this same approach can also be used in relation to arguing that migrants are taking jobs from the native population.

Knowledge is of course central to decisions, but at the same time, there are also differences in individuals' preferences and ideological beliefs that will, 
and should, have an impact on democratic decisions on social development. But if decisions are made in a void, for example without the inclusion of knowledge, then the risk of unintended effects of changes in welfare systems is greater. There are thus a number of balances that need to be kept in mind, and it is not a matter of whether different parts of the brain influence decisions. This is the discussion on system 1 (the quick and automatic part of the brain) and system 2 (slow, but also concentrated and able to do complex calculations), which was made famous by Kahneman (2012). Even though not everyone agrees with this understanding of the brain's way of functioning, here the aim is more to focus on the fact that most people, including this author, find it easier sometimes to remember a good story than an in-depth and informed analysis with many details, tables and figures trying to show the often very complicated relation between different aspects of societal development.

Some myths and narratives go viral and the focus will mainly be on myths that appear to have influenced the development of welfare states, for example as arguments for changes in the layout of the welfare state, the generosity of benefits and/or who should have access to a variety of welfare services. The myths and narratives are partly based on what has been found in a number of the references used in the book, but analysed in concert with the reading and interpretation of developments in welfare states in Europe through comparative analysis thereof. Therefore, in some countries there may be perceptions that other myths are more important to focus on than those chosen here. There are many and varied myths about welfare states. An example from a UK think tank, of a list of myths, is the following:

\footnotetext{
Myth 1: There are generations of workless, work-shy families

Myth 2: Benefits are too generous

Myth 3: Spending on benefits is out of control

Myth 4: The benefit bill is high because of cheats and fraudsters

Myth 5: Universal benefits are expensive and inefficient

Myth 6: Most claimants are sitting at home on benefits for years

Myth 7: Many people choose to claim disability benefits rather than work

Myth 8: Most benefit spending goes on the unemployed

Myth 9: The number of people claiming out-of-work benefits is increasing year on year

Myth 10: We are spending vast amounts on huge families with hordes of children

Myth 11: The benefits system encourages couples to split up

Myth 12: Work is always the best route out of poverty ${ }^{2}$
}

It is not the place here to enter into a discussion of these in detail, but overall, they revolve around issues of generosity, who gets the benefits, that they are too expensive and that there are benefits cheats. In this book, nine different myths are discussed, often resembling those listed above, and the causes and reasons for them are examined, such as the impact of technological develop- 
ment. The choice has been to analyse the following nine myths, which will be elaborated below and in the following chapters:

There is no alternative as the welfare state is too big

Unemployed - the stories of laziness

Migrants take our jobs and use and misuse the welfare system

People believe benefits are higher than they are

There has been austerity and retrenchment

Understanding of the impact of equality and poverty

Technological development is only good for society

Lowering of taxes will make everyone richer

It should pay to work - the economic incentives of work always have a positive impact

See further the brief description of each chapter in Section 1.2.

To give another example, part of which is returned to in Chapter 3, one myth related to the US welfare state is that it is very small and a welfare state laggard. Often, more generally, that the welfare state reduces productivity and economic growth (Garfinkel and Smeeding 2015). The first issue about whether the welfare is large in the US is in fact the story about whether occupational and fiscal welfare is included in the analysis (Greve 2014, 2018; Morel, Touzet, and Zemmour 2018b; Sinfield 2019), that is, that only looking at direct public spending reduces the estimated size of the welfare state including the level of spending. In the US it is argued that employer-provided welfare will increase the size of the welfare state by 50 per cent (Greve 2014, 2018; Morel, Touzet, and Zemmour 2018b; Sinfield 2019). The lack of hidden aspects of development thus blurs voters' understanding of the size and composition of welfare states (Greve 1994; Hacker 2004; Morel, Touzet, and Zemmour 2018a), and might create the myth of a smaller welfare state than is actually the case. This partly also shows that, for some, a hidden welfare state is better as it makes it easier to hide the fact that they get a different kind of support from the state.

However, not only are narratives and myths important to understand the development of welfare states, they presumably also influence the attitudes to welfare states, which again will influence decision makers. Therefore, a variety of different attitudes will be part of the discussion throughout the book.

Here, to give an indication, overall knowledge on attitudes to welfare states in Europe just before the outbreak of the financial crisis were:

Higher social security spending does not diminish individual acts of social support

- There is no evidence for the notion that the welfare state "crowds out" social solidarity 
- The higher the average income in a country, the more inclined are its citizens to provide for one another

- Economic security strengthens rather than weakens social ties, perhaps because individuals more readily turn their attention to others only once their own basic needs are met. $^{3}$

This can help in understanding why there is a dissimilar impact on different types of welfare states even though the data used for this conclusion are only up to 2008. There has been a change in the support for migrants, and in 2014 the most supportive were in Sweden with the least in the Czech Republic. ${ }^{4}$ Thus, the impact of the free movement of workers within the European Union, and migrants and refugees and their impact on an individual person's life condition will be a theme of several chapters.

For methodological reasons, this book does not aim to show whether or not there is causality, but rather indicates whether or not there are plausible connections.

\subsection{OVERVIEW OF THE BOOK}

After this first chapter, the next chapter aims at presenting what is understood by some of the central concepts running through and used within the book. This includes how to understand narratives, and a discussion on when they go viral (Shiller 2019), thereby also discussing why something which might not, in fact, be the reality influences policy decisions in welfare states. Central concepts to be presented are narrative, myths, deserving, legitimacy and welfare chauvinism. Also because they might interact, some myths, in fact, seem to have the aim of delegitimizing some people's access to benefits and/ or services.

In order to have an empirical background for the discussion of the core topics of the book, the third chapter will show the development in spending on welfare state activities, level of taxation, labour supply and equality (see also the different myths and topics in the other chapters for an explanation of why these elements have been included). These data help to depict the central elements of welfare states' positions and rationalities for their development, including how to finance these. A short section will also discuss the approach (myth) of "there is no alternative" and arguments therefore, as well as the often argued pressure on welfare states due to demographic changes, especially the growing number of elderly (Diamond and Lodge 2014), which has influenced pensions as well as long-term care (Greve 2016). The arguments that the welfare state is growing larger and larger - as a myth - will also be touched upon, including that measuring the size of the welfare state is not an easy issue, and this might influence the impact of different myths. 
In the fourth chapter the analysis will start revolving around the specific myths and narratives discussed in the book. Each chapter will look into one of them, and in Chapter 4 the focus is on one of the debates, which in fact has been around for some time. This is whether the unemployed are lazy and like to live on benefits or are actually searching for a job. Change in welfare state policies towards stronger activation is part of this debate, including that any job is better than no job. It includes the debates on workfare as a consequence of the understanding of the unemployed living on benefits instead of working, and also change in replacement rates as a possible consequence of the debate on the lazy unemployed. Lastly, conditionality is discussed, as change herein might also be due to the perception of laziness.

Another constant myth has been that migrants take jobs from the native population and also that there is welfare tourism. In Europe this also includes the free movement of workers within the European Union. Chapter 5 presents this discussion and whether or not this is the case overall. This is not to neglect the fact that there might be individual persons challenged by migrants at the micro level by, for example, different types of social dumping, but that this might not be the case if looking at the overall societal level. It will also reflect upon whether or not migration and migrants' use or misuse of benefits are seen as a problem, and change herein over time. The chapter also focuses on one issue that will be returned to in several chapters, the possible difference at the micro level and the societal level.

Even if people are in favour of or against the size of specific welfare benefits, it raises the question, in Chapter 6, as to whether this is based on factual knowledge of the size of the benefit or whether the understanding of the misuse of benefit - the existence of so-called benefits queens and welfare scroungers - is based on a lack of knowledge of the actual size of the benefits, so that if people overestimate the value of the benefits, this can influence their support for welfare states. They might compare the support with their own income, even though they might not be informed about the difference in level before and after tax and the possible change in other social benefits. Therefore, there are many elements making it possible that people are not aware of the factual size of the benefit and the impact on disposable income, but still have a strong view especially if individual cases have been discussed in public.

Pressure groups have an interest in promoting that their activities will be able to do a lot of good things if they get more money, and that if they are in danger of having less money available for their activities this will be detrimental for many deserving people and for societal development. A discussion hereabout is the focus of Chapter 7. So, if one is able to show that for a small amount of money from those paying one can do a lot of good things, this might put strong pressure on decision makers to increase spending in welfare states. This is in line with the classical thesis of the asymmetric growth in public 
sector spending. The chapter will draw on the data, as presented in Chapter 3 , to argue whether or not this has been the case. Further, based on existing research, it will give examples of how these tendencies have been used to argue for growth in specific areas of welfare states.

There have been growing levels of inequality and also of poverty in most European welfare states over the last $10-15$ years. This raises the question, in Chapter 8, of how this relates to the understanding of deservingness and willingness to pay tax (returned to in Chapter 10). This is further a contradictory case as some might be willing to support those in need, but the way they support change in different kinds of benefit to those they deem undeserving might imply a growth in inequality and poverty, and thereby more people in need. The complexity of the welfare system also makes it difficult sometimes to make change without it having an impact on people who are either seen as deserving or undeserving.

Technological unemployment is a long-standing issue, and with the discussion of the fourth industrial revolution (Schwab 2016; Affairs 2017), this occurs even more on the agenda as a story about losing jobs due to change on the labour market, and will be the focus of Chapter 9. The debate here revolves around not only the impact, but also who wins and who loses as part of the development. There is a case of possible societal gain, but also of a group of people at the micro level who are losing out. The debate also includes when and why the welfare state has a role, as classical in the active labour market policy, of correcting the outcome of market forces, but also how to ensure redistribution in such a way that the winners of the change support the losers.

A persistent myth has been that if taxes are reduced, especially on companies and high-income earners, this would imply higher economic growth and, by this, all would be richer in the different societies. This will be the focus in Chapter 10, which will discuss the myth that "the rising tide lifts all the boats", which implicitly argues that even if the rich get richer, this would also benefit those on low income, or even those living in poverty. The chapter will discuss whether this is, in fact, correct.

Part of the debate on changes in different kinds of welfare benefits has been that the economic incentive to take up work (in fact any job) should be a strong difference in economic living conditions when working or not working, and this is the focus of Chapter 11. This is implicitly a way of distinguishing between those seen as deserving and non-deserving. It shows a difference in possible option for welfare state intervention, but also implicitly an understanding by some that many only work for money, and that no other types of issues are related to having a job. Furthermore, the chapter will discuss whether there is knowledge about the size of the difference needed in order to have a sufficiently strong incentive to search for a job. It also builds upon an 
implicit understanding that it is the supply of labour that is most important for the level of employment, and not related to the demand for labour.

The last chapter will sum up and discuss what the implications of myths and narratives are for welfare states' development and future.

\subsection{DELIMITATIONS}

There are, as always, a number of issues not included in the book, some of which are depicted briefly below.

The book will not discuss what can be interpreted as a welfare state and how to understand what a welfare state is (Greve 2008, 2020d), despite it having been argued that the welfare state "is one of the most misleading, mythifying, and deceitful of all political terms today" (Douglas 2017,6), which is especially the case in the US and partly why the focus is mainly on Europe, but also that central to the book are myths which might change the role and size of the welfare state.

What is not included in detailed analysis is whether, as often claimed, there has been austerity (Greve 2020a), and also the debate on the impact of New Public Management (NPM), including whether control and measurement has reduced the quality of welfare services. Some data will albeit be presented in Chapter 3.

Even though the demographic changes are briefly included in Chapter 3, there is no detailed discussion on whether the change in demography is a threat to welfare states, or sometimes labelled a bomb (Greve 2006). Indirectly, the change in demography is partly a discussion on the impact of technological change, and the ability to finance the welfare states given the expected increase in spending on pensions, health and long-term care.

Another way to deal with narrative would have been to look into what is important for people in their daily life in order to have a high level of well-being, as this is also an indication of what does not matter, and thus stories hereabout might have an impact on, and the level of, ambitions to change welfare states. At the same time, if myths seem to indicate that people will lose something they really value, then this can change their perception about what they support. There has been, in recent years, an increase in the knowledge about well-being and happiness in welfare states. There is a lot of international work on the issue by institutions such as the Organisation for Economic Co-operation and Development (OECD) and the European Union. Knowledge on what is important for people will, at least indirectly, be used. However, for those wanting to look into these issues in more depth, see, for example, the World Happiness Report ${ }^{6}$ (see also Kahneman 1999; Easterlin 2013; Greve 2017b; Balestra, Boarini, and Tosetto 2018). 
That people's own unemployment can have a lasting impact on their attitudes towards welfare states at the overall societal level is not surprising. However, it is difficult to look into this using an overall comparative approach. For an example, however, see a Dutch study (Naumann, Buss, and Bähr 2016). Overall, at the same time change in societal development did not have an impact on the viewpoints related to health care and pensions. A UK study showed that even in times of a high level of unemployment, some believed that people could find a job if they really wanted one (Deeming and Johnston 2018) (see more on this in Chapter 4).

The focus is on welfare in nation states, thus arguments that the European Union should do something or have common solutions to welfare issues are not included (see instead, e.g. Baute, Meuleman, and Abts 2019) - with the exception of the possible impact on the free movement of workers as this has an impact on migration and viewpoints related to migrants' use of welfare benefits.

In the Nordic welfare states, there have been debates on whether welfare states have been able to support those most in need in a good way, but also that receiving benefits is attached with stigma. This is a myth that is still discussed (Hansen 2018), as is the debate on the efficiency of administrations, but not included in the book.

Attitudes can have an impact on social cohesion, as this also includes attachment, belonging and feelings of solidarity. However, the concept will not be discussed (see instead, Schiefer and Van der Noll 2017), but is still referred to in the book.

Naturally, there are issues related to how to measure welfare attitudes, including the situation of those responding to questions (Tepe and Vanhuysse 2020). Here it will be assumed, especially for those where data are available over a longer time-span, that on average this does not change and thereby has no impact on the analysis.

Other narratives and areas might have been chosen, but given the studies are mainly national, and are on more specific subsections of welfare states, they have not been included. See, for example, one on disability (Needham and Dickinson 2018) and on social impact bonds (Fraser et al. 2018).

\subsection{CONCLUSIONS}

This chapter has presented an overview of the book. It has also described a number of the themes that are central throughout the book's analysis. It includes why narratives can help to understand the evolution of welfare states and that some narratives go viral, while others do not. At the same time, it includes a number of existing myths that may have an impact on the development of welfare states, and which may be influenced by different degrees 
of knowledge about both services and benefits and who actually has access to a range of the various welfare states' offerings.

The chapter has presented the nine myths that are analysed in more detail throughout the book, along with the framework for the book's analyses. In doing this, the chapter has set the scene for the book and also showed that a magnitude of possible explanations is possible and that a variety of sources are needed in order to discuss the development of welfare states. These include quantitative data on actual development in the welfare states, but also stories and understanding of the development, together with survey data showing the subjective positions of the citizens. Lastly, it has been shown that there can be variations at both macro and micro levels of societies, and even at the micro level there might be winners and losers.

\section{NOTES}

1. European Social Survey (2018 data), published 31 October 2019 at https://www .europeansocialsurvey.org/, accessed 7 September 2020.

2. From http://classonline.org.uk/docs/2013_Exposing_the_myths_of_welfare.pdf, accessed 19 November 2019.

3. https://www.europeansocialsurvey.org/docs/findings/ESS1-3_findings_booklet .pdf, accessed 22 November 2019. Based on the first three rounds of the European Social Survey (ESS), thus, before the financial crisis and lively discussion on migration.

4. https://www.europeansocialsurvey.org/about/singlenew.html?a=/about/news/ essnews0075.html, accessed 22 November 2019.

5. John F. Kennedy, from https://www.jfklibrary.org/learn/about-jfk/jfk-in-history/ john-f-kennedy-on-the-economy-and-taxes, accessed 13 November 2019. Whether it was, in fact, quoted first by John F. Kennedy is not important here.

6. https://worldhappiness.report, accessed 18 March 2020.

\section{REFERENCES}

Affairs, Global. 2017. "The Fourth Industrial Revolution.” https://doi.org/10.17226/ 24699.

Balestra, Carlotta, Romina Boarini, and Elena Tosetto. 2018. "What Matters Most to People? Evidence from the OECD Better Life Index Users' Responses." Social Indicators Research 106 (3): 907-30. https://doi.org/10.1007/s11205-016-1538-4.

Baute, Sharon, Bart Meuleman, and Koen Abts. 2019. "Welfare State Attitudes and Support for Social Europe: Spillover or Obstacle?” Journal of Social Policy 48 (1): $127-45$.

Béland, Daniel, and Edella Schlager. 2019. "Varieties of Policy Feedback Research: Looking Backward, Moving Forward." Policy Studies Journal 47 (2): 184-205.

Cromby, John, and Martin E.H. Willis. 2014. "Nudging into Subjectification: Governmentality and Psychometrics." Critical Social Policy 34 (2): 241-59. 
Deeming, Christopher, and Ron Johnston. 2018. "Coming Together in a Rightward Direction: Post-1980s Changing Attitudes to the British Welfare State." Quality \& Quantity 52 (1): 395-413.

Diamond, P., and G. Lodge. 2014. "Dynamic Social Security after the Crisis: Towards a New Welfare State?" International Social Security Review 67 (3-4): 37-59. https:// doi.org/10.1111/issr.12047.

Douglas, Jack D. 2017. The Myth of the Welfare State. Oxon: Routledge.

Easterlin, R. 2013. "Happiness, Growth, and Public Policy." Economic Enquiry 51 (1): $1-15$.

Fraser, Alec, Stefanie Tan, Mylene Lagarde, and Nicholas Mays. 2018. "Narratives of Promise, Narratives of Caution: A Review of the Literature on Social Impact Bonds." Social Policy \& Administration 52 (1): 4-28.

Garfinkel, Irwin, and Timothy M. Smeeding. 2015. "Welfare State Myths and Measurement." Capitalism and Society 10 (1): 1-26.

Gladwell, Malcolm. 2006. The Tipping Point: How Little Things Can Make a Big Difference. London: Little, Brown.

Greener, I., and B. Greve. 2013. Evidence and Evaluation in Social Policy. Cheltenham, UK and Northamptonn, MA, USA: Edward Elgar. https://doi.org/10.1002/ 9781118816530 .

Greve, B. 1994. "The Hidden Welfare State, Tax Expenditure and Social Policy: A Comparative Overview." Scandinavian Journal of Social Welfare 3 (4): 203-11. https://doi.org/10.1111/j.1468-2397.1994.tb00227.x.

Greve, B. 2006. "Is There a Demographic Time-Bomb?" In The Future of the Welfare State. European and Global Perspectives, edited by B. Greve, 1st edn, 27-36. Hampshire, UK: Ashgate.

Greve, B. 2008. "What Is Welfare?” Central European Journal of Public Policy 2 (1): $50-73$.

Greve, B. 2014. "Occupational and Fiscal Welfare in Times of Crisis." Social Policy Review 26: Analysis and Debate in Social Policy, 2014.

Greve, B. 2016. Long-Term Care for the Elderly in Europe: Development and Prospects, edited by B. Greve, 1st edn. Oxon: Routledge. https://doi.org/10.4324/ 9781315592947.

Greve, B. 2017a. Handbook of Social Policy Evaluation, 1st edn. Cheltenham, UK and Northampton, MA, USA: Edward Elgar. https://doi.org/10.4337/9781785363245.

Greve, B. 2017b. "How to Measure Social Progress?" Social Policy \& Administration 51 (7): 1002-22. https://doi.org/10.1111/spol.12219.

Greve, B. 2018. "At the Heart of the Nordic Occupational Welfare Model: Occupational Welfare Trajectories in Sweden and Denmark." Social Policy \& Administration 52 (2): 508-18. https://doi.org/10.1111/spol.12380.

Greve, B. 2019. Welfare, Populism and Welfare Chauvinism. Bristol: Policy Press.

Greve, B. 2020a. Austerity, Retrenchment and the Welfare State. Truth or Fiction? Cheltenham, UK and Northampton, MA, USA: Edward Elgar.

Greve, B. 2020b. Poverty. The Basics. Oxon: Routledge.

Greve, B. 2020c. The Routledge International Handbook of Poverty, edited by B. Greve, 1st edn. Oxon: Routledge.

Greve, B. 2020d. Welfare and the Welfare State: Central Issues Now and in the Future. Oxon: Routledge.

Hacker, Jacob S. 2004. "Privatizing Risk without Privatizing the Welfare State: The Hidden Politics of Social Policy Retrenchment in the United States." American Political Science Review: 243-60. https://doi.org/10.1017/S0003055404001121. 
Hansen, Hans-Tore. 2018. "Myten Om Velferdsstaten." In Myter Om Velferd Og Velferdsstaten, 15-37. Oslo: Cappelen Damm Akademisk.

Jensen, Tracey, and Imogen Tyler. 2015. "'Benefits Broods': The Cultural and Political Crafting of Anti-Welfare Commonsense." Critical Social Policy 35 (4): 470-91. https://doi.org/10.1177/0261018315600835.

Jurado, Elena, and Grete Brochmann. 2013. Europe's Immigration Challenge: Reconciling Work, Welfare and Mobility. London: IB Tauris.

Kahneman, Daniel. 1999. "Objective Happiness." In Well-being: The Foundations of Hedonic Psychology. https://doi.org/10.1007/978-3-540-68540-1_1.

Kahneman, Daniel. 2012. Thinking, Fast and Slow. New York: Penguin Books.

Laenen, Tijs. 2018. "Do Institutions Matter? The Interplay between Income Benefit Design, Popular Perceptions, and the Social Legitimacy of Targeted Welfare." Journal of European Social Policy 28 (1): 4-17.

McGarvey, Darren. 2018. Poverty Safari: Understanding the Anger of Britain's Underclass. Edinburgh: Picador.

Morel, Nathalie, Chloé Touzet, and Michaël Zemmour. 2018a. "From the Hidden Welfare State to the Hidden Part of Welfare State Reform: Analyzing the Uses and Effects of Fiscal Welfare in France." Social Policy \& Administration 53 (1): 34-48. https://doi.org/10.1111/spol.12416.

Morel, Nathalie, Chloé Touzet, and Michaël Zemmour. 2018b. "Fiscal Welfare in Europe: Why Should We Care and What Do We Know so Far?" Journal of European Social Policy 28 (5): 549-60. https://doi.org/10.1177/0958928718802553.

Naumann, Elias, Christopher Buss, and Johannes Bähr. 2016. "How Unemployment Experience Affects Support for the Welfare State: A Real Panel Approach." European Sociological Review 32 (1): 81-92.

Needham, Catherine, and Helen Dickinson. 2018. "“Any One of Us Could Be among That Number': Comparing the Policy Narratives for Individualized Disability Funding in Australia and England." Social Policy \& Administration 52 (3): 731-49.

OECD. 1981. The Welfare State in Crisis. Paris: OECD.

Oorschot, Wim van. 2006. "Making the Difference in Social Europe: Deservingness Perceptions among Citizens of European Welfare States." Journal of European Social Policy 16 (1): 23-42. https://doi.org/10.1177/0958928706059829.

Schiefer, David, and Jolanda Van der Noll. 2017. "The Essentials of Social Cohesion: A Literature Review." Social Indicators Research 132 (2): 579-603.

Schwab, K. 2016. The Fourth Industrial Revolution. Davos: World Economic Forum.

Shiller, Robert J. 2019. Narrative Economics: How Stories Go Viral and Drive Major Economic Events. Princeton: Princeton University Press.

Sinfield, A. 2019. "Fiscal Welfare." In The Routledge Handbook of the Welfare State, edited by B. Greve, 2nd edn, 23-33. Oxon: Routledge.

Svallfors, Stefan. 2012. Contested Welfare States: Welfare Attitudes in Europe and Beyond. Stanford: Stanford University Press.

Tepe, Markus, and Pieter Vanhuysse. 2020. "Taking Social Policy Personally: How Does Neuroticism Affect Welfare State Attitudes?" Social Policy \& Administration. https://doi.org/10.1111/spol.12568.

Wenzelburger, Georg, and Felix Hörisch. 2016. "Framing Effects and Comparative Social Policy Reform: Comparing Blame Avoidance Evidence from Two Experiments." Journal of Comparative Policy Analysis: Research and Practice 18 (2): $157-75$. 